\title{
Methodology for profitability assessment in the case of old rolling stock replacement with new trains in Bulgarian State Railways
}

\author{
Valeri Stoilov ${ }^{1, *}$, Kiril Velkov ${ }^{1}$, Oleg Krastev $^{1}$, and Svetoslav Slavchev ${ }^{1}$ \\ ${ }^{1}$ Technical University - Sofia, Department of Railway Engineering, 8 Kliment Ohridski Blvd., 1000 Sofia, Bulgaria
}

\begin{abstract}
A methodology has been developed for assessing the profitability of passenger carriers in the event of a complete or partial replacement of the old rolling stock with new one. The evaluation has taken into account the energy costs, the cost of servicing the train stock, repair costs, the cost of infrastructure charges, the number of days for the movement of trains. A correction coefficient was introduced for bringing the analysed costs closer to the real ones reported in the accounting documents of BDZ-PP Ltd. It was found out that when the rolling stock is completely changed, company's expenses are expected to decrease by BGN 82 million per year. The most significant share is due to a decrease in energy resources $-51 \%$, followed by repair $-39 \%$, train staff $-17 \%$ and infrastructure fees $-16 \%$.
\end{abstract}

\section{Introduction}

Railway rolling stock used for passenger services is of crucial importance for the profitability of railway operators.

Railway vehicles at present used in BDZ - Passenger Services Ltd. (BDZ-PS) fleet have been in service for more than thirty years, are too old and in bad technical condition, so they make worse economical indexes of the enterprise. In order to overcome this negative trend and make transport service more attractive and thus increase the number of passengers, the management of the national railway operator - BDZ-PS is planning to buy modern rolling stock. In accordance with this expert opinion from Technical University of Sofia, from Department of Railway Engineering in particular, was commissioned. The task was to develop methodology for profitability assessment in case of old rolling stock replacement.

\section{Methodology for profitability assessment in case of old rolling stocks replacement with new trains}

This methodology contains the main principles and algorithms for profitability estimation of a new trains purchase for BDZ-PS fleet. It is based on costs calculation using:

- railway vehicles in the fleet now;

- new trains which would replace the rolling stock in service now.

The principles for calculating the annual costs for the present rolling stock and the new trains are absolutely the same. For that purpose the costs for every train on the timetable are calculated. All trains costs and total cost for the BDZ-PS $-R_{\Sigma}$ is the sum total of all trains costs. The costs for every train are calculated according to formula (1):

$$
R_{j}=\left(R_{1 j}+R_{2 j}+R_{3 j}+R_{4 j}\right) N_{j} k,
$$

where $R_{1 j}$ are energy (electric or diesel fuel) costs, lv.; $R_{2 j}$ -locomotive and train crew costs calculated for a particular train, lv.; $R_{3 j}$-tractive rolling stock maintenance costs, lv.; $R_{4 j}$ - infrastructure charge for the train, lv.; $N_{j}$ - number of the days for a given train movement, according to the timetable; $k$ - correctional coefficient which adduces costs from the other parameters in (1) to the real ones accounted for in BDZ-PS reports. It is used because part of the real costs do not depend on features of service and it is not included in formula (1).

The energy costs $R_{l j}$ are calculated according to the formula (2):

$$
R_{1 j}=W_{j} C,
$$

where $W_{j}$ is the work done by the train, and it is defined by the multiplication of the gross weight of the train and transport distance, t.km; $C$ - the value of the energy source, lv./t.km.

The paper uses average costs for the electric locomotives while the costs for the diesel locomotives are differentiated according to their series. This is official information from BDZ-PS and is shown in Table 1.

Locomotive and train crew costs $R_{2 j}$ are calculated according to formula (3):

$$
R_{2 j}=H_{j} \sum_{i=1}^{5} n_{i} S_{i}
$$

\footnotetext{
Corresponding author: vms123@tu-sofia.bg
} 
where $H_{j}$ is the work time for serving the train and it is defined as the sum of the train movement time, 1-hour time for preparation and 0,5 -hour after train arrival time according to the timetable; $n_{i}-$ the number of locomotive and train crew members such as a locomotive driver, train master, conductor and others; $S_{i}$ - the hourly rate for the different crew members in BDZ-PS: locomotive driver $11,28 \mathrm{lv} . / \mathrm{h}$, assistant locomotive driver $-8,14 \mathrm{lv} . / \mathrm{h}$, train master $-7,46 \mathrm{lv} . / \mathrm{h}$.

The tractive rolling stock maintenance costs $R_{3 j}$ are calculated according to formula (4):

$$
R_{3 j}=L_{j} S_{r}
$$

where $L_{j}$ is the distance between the initial and final station of the train destination, $\mathrm{km} ; S_{r}$ - the tractive rolling stock current maintenance costs, lv. $/ \mathrm{km}$.

The infrastructure charge for each train on the timetable is defined by means of the National Railway Infrastructure Company methodology using formula (5):

$$
R_{4 j}=L_{j} S_{v}+M_{j} L_{j} S_{b}=L_{j}\left(S_{v}+M_{j} S_{b}\right),
$$

where $L_{j}$ is as in (4); $S_{v}$ - the costs for a train per kilometer of the train movement, $S_{v}=0,7902 \mathrm{lv}$./train.km; $M_{j}-$ the train gross weight, t; $S_{b}$ - the costs rate per gross-tonkilometer, $S_{b}=0,0025, \mathrm{lv}$. $/ \mathrm{gtkm}$.

The overall costs of BDZ-PS for transportation are a sum which includes the costs for all trains, (6):

$$
R_{\Sigma}=\sum_{j=1}^{n} R_{j},
$$

where $n$ is the number of the all trains.

Table 1. Value of the energy source.

\begin{tabular}{|l|c|}
\hline Rolling stock & C, lv./t.km \\
\hline Electric & 0,01000 \\
\hline Diesel locomotive series 07 & 0,04649 \\
\hline Diesel multiple unit (DMU) series 10 & 0,01962 \\
\hline Diesel locomotive series 55 & 0,06587 \\
\hline Diesel locomotive series 75 & 0,05840 \\
\hline Diesel locomotive series 77 & 0,06056 \\
\hline
\end{tabular}

\section{Efficiency of replacement of the whole fleet}

Efficiency of replacement of the whole fleet without available DMU series 10 and electric multiple unit (EMU) series 30 and 31 is defined for the different types of trains with the aim to:

- estimate the overall efficiency of tractive rolling stock (RS) replacement;

- suggest a strategy for priority replacement of the type of trains in order to fulfill the timetable requirements.

The methodology for profitability assessment described in part 2 was used to do the estimation. The data about the available rolling stock: the value of the energy source, the hourly rate for the different crew members etc. are shown in BDZ-PS official account report for 2016.
The information was used for the new trains as follows:

- the value of the energy source, lv./t.km - the values are averaged according to catalogue information from different leading producers. These values are on average by $20 \%$ less than the values for the electric locomotives series 44, 45, 46, 61, and EMU series 32 and diesel locomotives series $07,55,75,77$ and they are on average equal to the values for DMU series 10 and EMU series 30, 31. These locomotives, DMUs and EMUs are in service at present;

- hourly rate for crew members, lv./h - the values are the same as the values on the BDZ-PS report now. The number of crew members is changed because the new trains do not require an assistant locomotive driver;

- tractive rolling stock current maintenance costs, lv./km are the same as these for DMU series 10 and EMU series 30 and 31 ;

- the infrastructure charges are calculated according to (5).

The summarized results from the calculation are shown in Table 2.

On the basis of the data in Table 2 the following conclusions have been made:

- in case of all fleet replacement the costs of BDZ-PS would be reduced;

- the values of the costs reduction are as follows: energy source $-51 \%$, rolling stock maintenance costs $-39 \%$, train crew costs $-17 \%$ and infrastructure charges $16 \%$;

- transportation by fast trains with obligatory passenger registration is the biggest part in cost reduction $-52,5 \%$, regional trains $-20 \%$, suburban trains $-16 \%$, and transportation on secondary railways $-11,5 \%$. On the basis of this data the priority of replacement has been defined.

\section{Profitability of rolling stock replacement until 2023}

The profitability of RS replacement over the period of up to 2023 is calculated according to the methodology described in part 2 under the following conditions [1-5]:

- six new speed trains are bought;

- ten new EMUs with four wagons and with a high level of comfort are bought;

- twenty-five EMUs with two and three wagons are bought.

The new rolling stock makes it possible to serve 109 trains on the timetable $[1,2]$. Their types and number are as follows:

- 12 speed trains with speed of operation $160 \mathrm{~km} / \mathrm{h}$;

- 26 fast trains with speed of operation $130 \div 140 \mathrm{~km} / \mathrm{h}$;

- 71 suburban, regional and trains on secondary railways.

Analysis of the results (Table 3 ) shows that the costs for all trains in the timetable have been reduced as follows:

- energy costs - by $20 \%$;

- current maintenance costs - by $14,5 \%$;

- infrastructure costs - by $6,9 \%$;

- train crew costs - by 5,5\%. 
Table 2. Summarized results from the calculation.

\begin{tabular}{|c|c|c|c|c|c|c|c|c|c|c|}
\hline \multicolumn{2}{|c|}{$\begin{array}{c}\text { Energy source } \\
\text { value per day, lv. }\end{array}$} & \multicolumn{2}{|c|}{$\begin{array}{l}\text { Train crew costs } \\
\text { per day, lv. }\end{array}$} & \multicolumn{2}{|c|}{$\begin{array}{c}\text { Current } \\
\text { maintenance costs } \\
\text { per day, lv. }\end{array}$} & \multicolumn{2}{|c|}{$\begin{array}{l}\text { Infrastructure } \\
\text { costs per day, lv. }\end{array}$} & \multicolumn{2}{|c|}{$\begin{array}{l}\text { General costs per year, } \\
\text { lv. }\end{array}$} & \multirow[t]{2}{*}{$\begin{array}{c}\text { Costs } \\
\text { reducing, lv. }\end{array}$} \\
\hline Present & New & Present & New & Present & New & Present & New & Present & New & \\
\hline \multicolumn{11}{|c|}{ Fast trains with obligatory passenger registration } \\
\hline 12005 & 4962 & 2623 & 1982 & 8506 & 4962 & 6502 & 5051 & 8666174 & 4960792 & 3705382 \\
\hline \multicolumn{2}{|c|}{$41 \%$} & \multicolumn{2}{|c|}{$24 \%$} & \multicolumn{2}{|c|}{$42 \%$} & \multicolumn{2}{|c|}{$22 \%$} & \multicolumn{3}{|c|}{$43 \%$} \\
\hline \multicolumn{11}{|c|}{ Fast trains } \\
\hline 68028 & 27466 & 20312 & 16016 & 43869 & 25701 & 34933 & 26638 & 92636413 & 52907055 & 39729358 \\
\hline \multicolumn{2}{|c|}{$60 \%$} & \multicolumn{2}{|c|}{$21 \%$} & \multicolumn{2}{|c|}{$41 \%$} & \multicolumn{2}{|c|}{$24 \%$} & \multicolumn{3}{|c|}{$43 \%$} \\
\hline \multicolumn{11}{|c|}{ Suburban trains } \\
\hline 37820 & 23737 & 26708 & 23665 & 28409 & 20711 & 24472 & 22062 & 59527065 & 46212198 & 13314867 \\
\hline \multicolumn{2}{|c|}{$37 \%$} & \multicolumn{2}{|c|}{$11 \%$} & \multicolumn{2}{|c|}{$27 \%$} & \multicolumn{2}{|c|}{$10 \%$} & \multicolumn{3}{|c|}{$22 \%$} \\
\hline \multicolumn{11}{|c|}{ Regional trains } \\
\hline 28919 & 15648 & 15355 & 12228 & 25328 & 15776 & 19154 & 16538 & 49981901 & 33339240 & 16642662 \\
\hline \multicolumn{2}{|c|}{$46 \%$} & \multicolumn{2}{|c|}{$20 \%$} & \multicolumn{2}{|c|}{$38 \%$} & \multicolumn{2}{|c|}{$14 \%$} & \multicolumn{3}{|c|}{$33 \%$} \\
\hline \multicolumn{11}{|c|}{ Trains on secondary rail ways } \\
\hline 27638 & 13358 & 12826 & 10655 & 8621 & 3397 & 7640 & 7147 & 22831040 & 13572488 & 9258552 \\
\hline \multicolumn{2}{|c|}{$52 \%$} & \multicolumn{2}{|c|}{$17 \%$} & \multicolumn{2}{|c|}{$61 \%$} & & & & $41 \%$ & \\
\hline & & & & & ieneral fc & $\mathrm{BDZ}-\mathrm{Ps}$ & & & & \\
\hline 174409 & 85197 & 77824 & 64547 & 115032 & 70546 & 92701 & 77436 & 233642594 & 150991773 & 82650821 \\
\hline & & & & & & & & & $35 \%$ & \\
\hline
\end{tabular}

Table 3. Summerized results from the calculation in the case of rolling stock replacement until 2023 (stage 1).

\begin{tabular}{|c|c|c|c|}
\hline $\begin{array}{c}\text { Annual costs } \\
\text { with available } \\
\text { rolling stock, } \\
\text { lv. }\end{array}$ & $\begin{array}{c}\text { Annual costs } \\
\text { with new } \\
\text { rolling stock, } \\
\text { lv. }\end{array}$ & $\begin{array}{c}\text { Annual costs } \\
\text { reduction, } \\
\text { lv. }\end{array}$ & $\begin{array}{c}\text { Costs } \\
\text { reduction, } \\
\%\end{array}$ \\
\hline 233642594 & 199481068 & 34161526 & $14,6 \%$ \\
\hline
\end{tabular}

\section{Profitability of rolling stock replacement until 2028}

The profitability of RS replacement in the second period from 2023 to 2028 is calculated according to the Methodology for profitability assessment described in part 2 of this paper under the following conditions [1, 2]:

- four new speed trains are purchased;

- ten new EMUs with four wagons and with a high level of comfort are purchased;

- thirty EMUs with two and three wagons are purchased.

The new rolling stock wil make it possible to serve 150 trains more than in stage $1[1,2]$. The types and number of trains are:

- 10 speed trains with a speed of operation $160 \mathrm{~km} / \mathrm{h}$;

- 48 fast trains with a speed of operation $130 \div 140 \mathrm{~km} / \mathrm{h}$;

- 92 suburban, regional and trains on the secondary railways.
After stage 2 costs reduction would be about 35 million lv., as compared to stage 1 , as a result of the replacement.

The calculations show that the costs for one destination of all trains in the timetable are reduced after stage 2 as follows:

- energy costs - by $18,9 \%$;

- current maintenance costs - by $12,96 \%$;

- infrastructure costs - by $6,9 \%$;

- train crew costs - by $5,4 \%$.

\section{General profitability of the rolling stock replacement until 2028}

The general profitability of RS replacement during the stage 1 and 2 is the sum total of the results calculated in part 4 and part 5 of this paper.

BDZ-PS costs reduction is about 70 million $l v$. annually and it means 30\% less in comparison with 2016. The results of the calculation show that after stages 1 and 2 costs reduction in comparison with 2016 are as follows:

- energy costs - 39\%;

- current maintenance costs - 27,5\%;

- infrastructure costs $-12,4 \%$;

- train crew costs $-10,9 \%$. 


\section{Conclusions}

1. Methodology for profitability assessment of the fleet replasment has been developed.

2. On the basis of this methodology the priority of the replacement is defined. It includes speed trains, regional, suburban and secondary railway trains.

3. BDZ-PS costs reduction levels are:

- up to 34 million lv. annually in comparison to 2016 year, after the end of the stage 1;

- additional up to 35 million lv. annully during stage 2 in comparison with stage 1;

- in general about 70 million annually in comparison with 2016 after stage 1 and 2.

4. Costs reduction due to the energy efficiency of the new trains, low level of current maintenance and infrastructure charges and crew costs.

The research shows that BDZ-PS has to replace RS in accordance with stage 1 and 2 [1-5]. As a result of this passenger transportation will be more comfortable and the return on investment will be within 6 to 8 years.

\section{References}

1. O. Krastev, K. Velkov, V. Stoilov, I. Petrov, S. Slavchev, Defining the number and the type of the BDZ - Passenger Services new trains, BulTrans-2017, (2017)

2. K. Velkov, O. Krastev, V. Stoilov, I. Petrov, S. Slavchev, Defining the main parameters of the BDZ Passenger Services trains, BulTrans-2017, (2017)

3. K. Velkov, O. Krastev, V. Stoilov, B. Damyanov, Opportunities for improve locomotives maintenance, BulTrans-2012, 15-20, (2012)

4. O. Krastev, K. Velkov, V. Stoilov, An appropriate system for attendance trains with locomotive crews, BulTrans-2012, 21-28, (2012)

5. V. Stoilov, K. Velkov, O. Krastev, The main economical indexes analyses of the locomotive maintenance in Bulgarian state railways passenger transportation, BulTrans-2012, 29-37, (2012) 